\title{
Litter Production and Decomposition Rate in the Reclaimed Mined Land under Albizia and Sesbania Stands and Their Effects on some Soil Chemical Properties
}

\author{
Ali Munawar, Indarmawan, and Hery Suhartoyo \\ Soil Science Laboratory, University of Bengkulu, Jalan Raya Kandang Limun, Bengkulu 38371 A. \\ Phone: 081227757795. Fax: +62 73621290, e-mail: a.munawar008@gmail.com
}

Received 17 May 2010 / accepted 8 November 2010

\begin{abstract}
Vegetation establishment is considered as a critical step of mined land rehabilitation. The growing plants do not only prevent soil erosion, but also play important roles in soil ecosystem development. Their litterfall is the main process of transferring organic matter and nutrients from aboveground tree biomass to soil. Thus, its quantification would aid in understanding biomass and nutrient dynamics of the ecosystem. This study was aimed to investigate the litter production and its decomposition rate in a reclaimed mined land using albizia and sesbania, and their effects on some soil properties. The litter under each stand was biweekly collected for four months. At the same time litter samples were decomposed in mesh nylon bags in soils and the remaining litters were biweekly measured. Soil samples were taken from $0-15 \mathrm{~cm}$ depths from each stand for analyses of soil organic C, total $\mathrm{N}$, and cation exchange capacity (CEC). The results demonstrated that total litter production under albizia $\left(10.58 \mathrm{tha}^{-1} \mathrm{yr}^{-1}\right) \mathrm{was}$ almost twice as much as that under sesbania stands $\left(5.43 \mathrm{t} \mathrm{ha}^{-1} \mathrm{yr}^{-1}\right)$. Albizia litter was dominated by leaf litter $(49.26 \%)$ and least as understory vegetation $(23.31 \%)$, whereas sesbania litter was more evenly distributed among litter types. Decomposition rates of all litters were fastest in the initial stage and then gradually decreased. Sesbania leaf litters decomposed fastest, while albizia twigs slowest. Differences in the litter production and decomposition rates of the two species had not sufficiently caused significant effects on organic- $\mathrm{C}$, total $\mathrm{N}$, and CEC of the soils after one year of revegetation.
\end{abstract}

Keywords: Albizia (Paraserianthes falcataria), decomposition rates, litter, mined land, Sesbania grandiflora

\section{INTRODUCTION}

Establishing vegetative cover (revegetation) is the first step in mined land rehabilitation and it is considered as a key success of the rehabilitation program. Although the original objective of revegetation is to prevent soil erosion, the standing vegetations have been reported to enhance the ecosystem development (Ruan et al. 2005; Singh et al. 2006). This is mainly resulted from the transfer organic matter and nutrient from aboveground biomass to the soil through their litterfalls or plant biomass (Brienza et al. 2000; Tripathi et al. 2005; Vivanco and Austin 2008; Tripathi et al. 2009).

Litterfalls, together with plant roots, form organic matter-rich soil layer and develop biological dynamics, where soil microorganisms and vegetation interact and perform ecological functions. Besides, vegetative cover provides shelter

J Trop Soils, Vol. 16, No. 1, 2011: 1-6

ISSN 0852-257X and structural complexity for wildlife, increases microbial activity, improves microclimatic conditions, reduces nutrient leaching, and enhances soil profile development (Lal et al. 1998; Shrestha and Lal 2008).

The effects of vegetative cover on soil ecosystem development is highly species dependent due to differences in litter production and quality, microclimate changes, and changes in edaphic conditions (Silver et al. 2000) such as water holding capacity, nutrient availability, and biological activity (Xiong et al. 2008). In their works on three species (Cythea latebrosa, Astronia spectabilis, and Syzygium spp.) in Mount of Tangkubanperahu, West Java, Indonesia, however, Rosleine et al. (2006) reported that these species varied in their litter production, and found that species with higher litter production did not always contribute greater nutrient to the soil. Plant nutrient supply from plant species to the soil was also affected by decomposition rates of the litter (Prescott 2005; Rosleine et al. 2006; Ibrahim et al. 2010). Species with fast decomposition rate provides high nutrient 
release, while slow decomposition implies nutrient retention in the ecosystem.

Based on the above information, it is necessary to quantify litter production and rate of the decomposition of litter from different species in order to better understand the biomass and nutrient dynamics in an ecosystem. This study was conducted to investigate litter production and decomposition rates in a recently-reclaimed mined land in North Bengkulu using albizia and sesbania and their effects on some soil properties.

\section{MATERIALSAND METHODS}

\section{Study Site Description}

The study was conducted in a coal mined land of PT Bukit Sunur located in North Bengkulu, about $35 \mathrm{~km}$ from Bengkulu city ( $3^{\circ} 46^{\prime} 45.62^{\prime \prime} \mathrm{S}$ latitude and $102^{\circ} 30^{\prime} 55.21^{\prime \prime}$ E longitude). The area of 0.25 ha has been reclaimed for one year using albizia [Paraserianthes falcataria (L.) Nielsen] and sesbania (Sesbania grandiflora Pers) tree plants with $2 \mathrm{~m} \times 2 \mathrm{~m}$ spacing. The original soil was around neutral ( $\mathrm{pH} 6.76$ at soil:water $=1: 2.5)$, low in most major nutrient elements particularly total microKjeldahl N (0.14\%) and available P-Bray 1 (1 ppm), and poor in biological activity (low in bacteria and fungi population). The soil was highly compacted with a re1atively high bulk density $\left(1.48-1.57 \mathrm{~g} \mathrm{~cm}^{-}\right.$ $\left.{ }^{3}\right)$ and low infiltration rate $\left(0.55 \mathrm{~cm} \mathrm{hr}^{-1}\right)$.

\section{Litter Production and N content}

Litter production was measured using a Ground Litter Sampling (GLS) technique. A wood square frame of $50 \mathrm{~cm} \times 50 \mathrm{~cm}$ was randomly placed on pre-cleaned soil surface from any detritus to collect litterfalls under each stand, with four sampling locations. The litterfalls consisting of leaves, twigs, and understory vegetations were collected every two weeks for four months. The harvested litters were separated into leaves, twigs, and understory vegetation, put in the paper bags, and oven-dried at $70^{\circ} \mathrm{C}$ until constant weight (48 hrs). Some ovendried leaf samples of both stands were ground for $\mathrm{N}$ content analyses using the wet destruction method (Sulaeman et al. 2005).

\section{Litter Decomposition Rates}

To calculate the decomposition rates, litterfalls consisting of most recently fallen leaf- and twiglitters were collected from soil surface under each stand and air-dried. The collected leaf- and twig- litters of 30 and $20 \mathrm{~g}$ were, respectively, weighed and separately put into nylon mesh bags. Twentyone (21) bags of weighed leaf and twig litters were separately placed into about $3-5 \mathrm{~cm}$ soil depth in each stand, and allowed to decompose. After 2, 4, $6,8,10,12$, and 14 weeks of the litter placement, three litterbags of each litter type were taken at random from each stand, and transported to the laboratory. The adhering soils, plant detritus and the "in-growth" roots were excluded, and remaining litter in litterbag was transferred into paper bags and then oven-dried at $70^{\circ} \mathrm{C}$ to constant weight for the determination of remaining weight. The decomposition rates were calculated using a simplified equation suggested by Olsen (Jordan 1985), as follows:

$$
W=W o-W t
$$

where $W$ is weight of the litter loss (decomposed) up to the sampling times, Wo is the original litter weight ( $30 \mathrm{~g}$ and $20 \mathrm{~g}$ for leaf and twig respectively), and $W t$ is remaining weight left at the sampling times. The remaining weight at time of observation was used to calculate the decomposition rate of the litter falls during the experiment.

\section{Soil Analyses}

To investigate the effects of litter production and the rates of decomposition under each stand on some soil chemical properties, five soil samples were randomly taken from each stand at $0-15 \mathrm{~cm}$ depths using soil cores, and collected into plastic bags to obtain composite samples. Four soil samples (as replication) from each stand were air-dried and brought to soil science laboratory of the Faculty of Agriculture, University of Bengkulu for analyses of total organic $\mathrm{C}$ and total N. Determination of the cation exchange capacity (CEC) was only carried out with two replications. The soil organic $\mathrm{C}$ and total $\mathrm{N}$ contents were, respectively, determined using Walkley \& Black and micro-Kjeldahl methods; whereas for soil CEC determination, the soil was extracted using $1 \mathrm{~N} \mathrm{NH}_{4}$-acetate $\mathrm{pH} 7$ and measured in the Spectrophotometer at $636 \mathrm{çm}$ (Sulaeman et al. 2005).

\section{Data Analyses}

Parts of the data were illustrated in the form of graphs. Analysis of variance (ANOVA) and ttest at $\mathrm{P}<0.05$ were employed. When treatment effects were significant, the treatment mean effects were analyzed using least significant different (LSD). 


\section{RESULTS DAN DISCUSSIONS}

\section{Litter Production}

Data on the average litter production during the experiments are given in Table 1. The total litter production of one-year old albizia stands was almost twice as much as that under sesbania stands, 88.13 $\mathrm{g} \mathrm{m}^{-2}$ month $^{-1}$ or $10.58 \mathrm{t} \mathrm{ha}^{-1} \mathrm{yr}^{-1}$ compared with $45.27 \mathrm{~g} \mathrm{~m}^{-2}$ month ${ }^{-1}$ or $5.43 \mathrm{t} \mathrm{ha}^{-1} \mathrm{yr}^{-1}$, although they were only significant different at $\mathrm{P}<0.10$. It has been documented that canopy and biomass production of albizia tree are larger than that of sesbania. The average height growth rate and height at maturity of albizia are $5 \mathrm{~m} \mathrm{yr}^{-1}$ and $45 \mathrm{~m}$, respectively compared to $3.3 \mathrm{~m} \mathrm{yr}^{-1}$ and $10 \mathrm{~m}$ of sesbania (Anonim 1984).

Biomass distribution of litters produced under different tree stands had different patterns (Table 1). Under albizia stands leaf litter constituted the highest percentage $(49.26 \%$ ), followed by twigs $(34 \%)$ and understory vegetations $(23.31 \%)$; whereas under sesbania stands the litter biomass was more evenly distributed among litter types.

At one-year old sesbania trees had better growth with average of $4.30 \mathrm{~m}$ height and $8.12 \mathrm{~cm}$ stem diameter compared to albizia which had 3.54 $\mathrm{m}$ height and $5.77 \mathrm{~m}$ stem diameter; however, albizia trees had a canopy with higher biomass density, resulting in higher litter production. Visual observation showed that sesbania stands had a larger number of dying branches and twigs, which consequently had contributed significant amounts of woody materials to the total litter biomass.

\section{Decomposition Rates of Litterfalls}

Data of decomposition rates of the litterfall are given in Table 2 and illustrated by Figure 1. The figure shows that all decomposition rates of all litter types were characterized by initial fastest rates in the first two weeks, followed by subsequent slower rates. In the initial decomposition process, easily decomposable plant components such as low molecular weight cellulolytic substances are released rapidly. After celluloses is decomposed and used by microorganisms, more recalcitrant substances (such as lignin and tannin) of the litterfalls remain; and consequently their decomposition rates decrease at advanced stage (Yang et al. 2003; Dux et al. 2006; Devi and Yadava 2007; Thripathi et al. 2009).

The lower loss of residue biomass at the weeks of 10 to 14 was likely due to relatively lower rainfall $(<100 \mathrm{~mm} / 2$ weeks) during these weeks compared to the earlier weeks ( $>100 \mathrm{~mm} / 2$ weeks). Under such drier conditions, temperature and moisture levels might have not favourable for microbial activity, resulting in lower decomposition process.

Table 2 shows that the fastest decomposition was found for leaf litter of sesbania. A $100 \%$ of the sesbania litter biomass had disappeared within earlier four weeks after decomposition, whereas biomass loss of the albizia leaf litter was the least with $78.70 \%$ loss after 14 weeks. In the early two weeks both leaf and twig litters of sesbania decomposed faster than both albizia leaves $(61.83 \%$ loss) and twigs (54.65\% loss). It was unexpected that woody materials of sesbania twigs were decomposed faster than albizia leaves, as usually reported that ligneous materials usually had slow decomposition rates (Rosleine et al. 2006). Similar phenomenon, however, was also reported by Devi and Yadava (2007). These workers found that wood litters of Dipterocarpus tuberculatus Roxb decomposed faster in the early stage in comparison with their leaf litters. They suggested that it was due to termite activity, which preferred to attack woody litters vigorously than the leaves. Therefore,

Table 1. The average litter production under albizia and sesbania stands.

\begin{tabular}{ccccc}
\hline \multirow{2}{*}{ Litter types } & \multicolumn{2}{c}{ Albizia } & \multicolumn{3}{c}{ Sesbania } \\
\cline { 2 - 5 } & $\mathrm{g} \mathrm{m}^{-2}$ month $^{-1}$ & $\%$ & $\mathrm{~g} \mathrm{~m}^{-2}$ month $^{-1}$ & $\%$ \\
\hline Leaf & $37.45 \mathrm{a}^{*}$ & 49.26 & $15.02 \mathrm{~b}$ & 33.18 \\
& $\mathrm{~A} * *$ & $\mathrm{~A}$ & \\
Twig & $29.96 \mathrm{a}$ & 34.00 & $14.82 \mathrm{~b}$ & 32.74 \\
& $\mathrm{AB}$ & $\mathrm{A}$ & \\
Understory & $20.72 \mathrm{a}$ & 23.31 & $15.43 \mathrm{a}$ & 34.08 \\
Vegetation & $\mathrm{C}$ & & $\mathrm{A}$ & \\
\hline Total & 88.13 & 100 & 45.27 & 100 \\
\hline
\end{tabular}

*Values in the same row followed by the same small letter are not significantly different at 0.05 probability level **Values in the same column followed by the same capital letter are not significantly different at 0.05 probability level. 
Table 2. Average leaf and twig litter loss during the decomposition under sesbania and albizia stands.

\begin{tabular}{|c|c|c|c|c|}
\hline \multirow{2}{*}{$\begin{array}{l}\text { Sampling time } \\
\text { (weeks) }\end{array}$} & \multicolumn{2}{|c|}{ Sesbania* } & \multicolumn{2}{|c|}{ Albizia } \\
\hline & Leaf & Twig & Leaf & Twig \\
\hline \multicolumn{5}{|c|}{ - } \\
\hline 0 & $0(0)$ & $0(0)$ & $0(0)$ & $0(0)$ \\
\hline 2 & $23(76.67)$ & $15.70(78.50)$ & $18.55(61.83)$ & $10.93(54.65)$ \\
\hline 4 & $30(100)$ & $18.70(93.50)$ & $26.75(89.17)$ & $18.59(92.95)$ \\
\hline 6 & $30(100)$ & $18.36(91.80)$ & $26.63(88.77)$ & $18.54(92.70)$ \\
\hline 8 & $30(100)$ & $18.11(90.55)$ & $25.95(86.50)$ & $18.29(91.45)$ \\
\hline 10 & $30(100)$ & $18.07(90.35)$ & $24.71(82.37)$ & $17.64(88.20)$ \\
\hline 12 & $30(100)$ & $17.61(88.05)$ & $24.35(81.67)$ & $17.42(87.10)$ \\
\hline 14 & $30(100)$ & $17.38(86.90)$ & $23.61(78.70)$ & $17.54(87.70)$ \\
\hline
\end{tabular}

*Numbers in the parentheses indicate percentage of biomass loss.

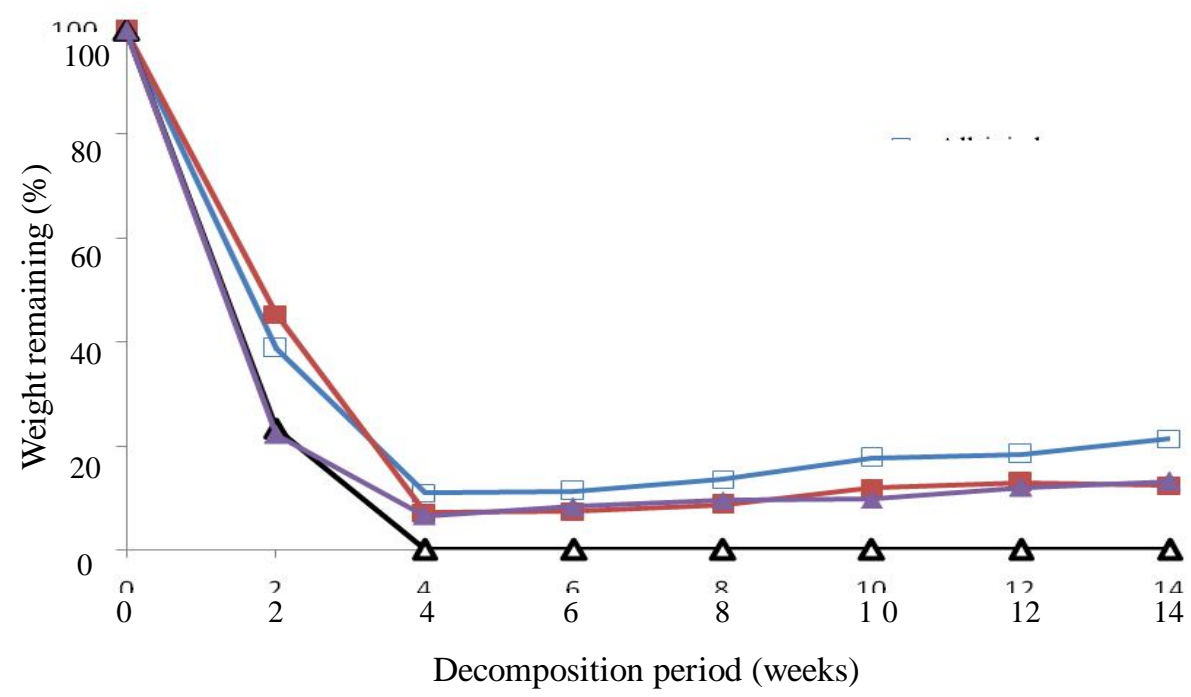

Figure 1. Percentage of albizia and sesbania litter remained after decomposition period.

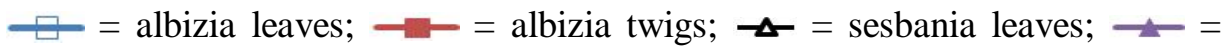
sesbania twigs.

feeding activities of termites had accelerated decomposition of sesbania twigs. The preference of termite to wood over leaf litter needs to be investigated further. This is also in line with earlier findings by Tian (1998). Tian found that macrofauna-mediated leaf decomposition in the degraded soil, like the mined soil used in this study, was higher than in the non-degraded soil. Most mined soils contain less organic matter and microorganisms, so macro-fauna might be dominant and play important roles in floor litter dynamics.

Litter decomposition is also influenced by physicochemical properties of the plant parts (stem wood, leaves, or roots) and decomposer organisms present in the soil and environmental factors (Devi and Yadava 2007). Higher N content of sesbania leaves $(2.38 \%)$ compared to that of albizia leaves (2.24\%) indicates that sesbania leaves were easily decomposed (Dux et al. 2006). Besides, our field observation also found that the leaves of sesbania were smaller and thinner than those of albizia. Smaller and thinner sesbania leaflets would have easily and well mixed with soil particles and consequently more accessible to microbial attacks during the decomposition process.

In addition, lesser density of sesbania stands in the field had caused the direct exposure of litter on soil surface to solar radiation and higher 
Table 3. Some chemical properties of the soils under albizia and sesbania stands.

\begin{tabular}{cccc}
\hline \multirow{2}{*}{ Tree Stand } & \multicolumn{3}{c}{ Soil chemical properties* } \\
\cline { 2 - 4 } & Organic C $(\%)$ & Total N $(\%)$ & CEC $\left(\mathrm{cmol} \mathrm{kg}^{-1}\right)$ \\
\hline \multirow{2}{*}{ Albizia } & $4.66 \mathrm{a}$ & $0.20 \mathrm{a}$ & $22.76 \mathrm{a}$ \\
Sesbania & $5.11 \mathrm{a}$ & $0.20 \mathrm{a}$ & $18.74 \mathrm{a}$ \\
\hline
\end{tabular}

*Values within a column followed by same letters were not significantly different at 0.05 probability level $(\mathrm{P}<0.05)$.

temperature (Anonim 1984; Xiong et al. 2008), thus accelerating litter decomposition. Presence of high portion of understory vegetation $(36.38 \%)$ under sesbania stands compared to that under albizia stands $(22.90 \%)$ might also favored litter decomposition. Xiong et al. (2008) reported that the decomposition rate of Acacia mangium litter within a year was two times faster $(75.2 \%)$ when understory vegetations were not removed as compared to that understory vegetations were removed $(37.2 \%)$. They attributed this to greater biological activity in the presence of understory vegetation.

\section{Chemical Properties of the Soil under Tree Stands}

Some chemical properties of the soils under albizia and sesbania stands are summarized in Table 3. Statistically, there were no significant differences in soil organic $\mathrm{C}$ and total $\mathrm{N}$ contents, and CEC of the soils under two different stands. This means that differences in biomass production and decomposition rate of litterfalls of one-year old albizia and sesbania stands had not sufficiently caused significant differences in the accumulation of soil organic matter, $\mathrm{N}$ release, and nutrient retention in the soil. Differences might occur with stand age as production of litterfall increases, mainly due to greater amounts of twigs, bark, and fruit that fall in older stands (Parsakhoo and Jalilvand 2009).

Rosleine et al. (2006) in their works with three species in Mount of Tangkubanperahu, West Java, found that species with fastest litter decomposition (Astronia spectabilis) provided higher nutrient release, while those with slow decomposition rate enhanced nutrient retention in the ecosystem. Based on these findings, therefore, due to its fast decomposition rate, the sesbania stands might more easily provide nutrient release. On the other hand, although their litterfalls have slower decomposition rates, due to their greater litter biomass production and longer life span than sesbania (Anonim 1984), in the long-term development albizia stands might have more sustained nutrient contribution and soil improvement in mined land ecosystem.

Although there were no differences in total $\mathrm{N}$ contents in soils in the two different stands, their $\mathrm{N}$ contents were much higher than the original soil $(0.14 \%)$ before revegetation. This means that revegetation had improved soil properties, including $\mathrm{N}$ supply.

\section{CONCLUSIONS}

Total litter biomass production under albizia stands was $88.13 \mathrm{~g} \mathrm{~m}^{-2}$ month ${ }^{-1}$ or $10.58 \mathrm{t} \mathrm{ha}^{-1} \mathrm{yr}^{-1}$, which was almost two times higher than that under the sesbania stands, $45.27 \mathrm{~g} \mathrm{~m}^{-2}$ month $^{-1}$ or $5.43 \mathrm{t}$ $\mathrm{ha}^{-1} \mathrm{yr}^{-1}$. Under albizia stands leaf litter constituted highest percentage $(49.26 \%)$ of the total litter biomass, followed by twigs $(34.00 \%)$, and understory vegetation $(23.31 \%)$; whereas under sesbania stands litter biomass was more evenly distributed to all litter types.

Litter decomposition was generally fastest in the initial stage of decompositions (2-4 weeks) and then gradually decreased. Sesbania leaf litters decomposed fastest (100\%) in the early four weeks, followed by sesbania twig, albizia leaf, and albizia twig litters. Differences in the amounts of biomass production and litter decomposition rates apparently had not sufficiently caused significant effects on organic-C, total $\mathrm{N}$, and CEC of the soils in the recently-reclaimed mined land within one-year period of the revegetation. Considering its longer life span, for long-term ecosystem development albizia might contribute more sustained effects on soil chemical properties. Further study on long-term effects of litter production and decomposition rate on soil properties, therefore, is needed.

\section{ACKNOWLEDGEMENTS}

The author thanks Edwin Martin and Supintri for their valuable helps during the field experiment and lab analyses. 


\section{REFERENCES}

Anonim. 1984. Agroforestry In-service Training: A Training Aid for Asia \& the Pacific Islands. Peace Corp Information Collection and Exchange. Training Manual T016. Peace Corp.

Brienza SJ, M Denich, H Folster and PLG Vlek. 2000. Litterfall and litter in enriched fallow with fast growing trees in the Eastern Amazon of Brazil. In: R Lieberei, H KV Boehm, and C Reisdorff (eds). Proceedings of the German-Brazilian Workshop on Neotropical-Achievements and Prospects of Cooperative Research. Hamburg, September 3-8, 2000, pp. 939-942.

Devi AS and PS Yadava. 2007. Wood and leaf litter decomposition of Dipterocarpus tuberculatus Roxb. in a tropical deciduous forest of Manipur, Northeast India. Curr Sci 93 (2): 243-246.

Dux J, L Norgrove, S Hauser, B Wick and R Kuhne. 2006. Plant leaf residue decomposition, nutrient release, and soil enzyme activity. Conference on International Agricultural Research for Development. University of Bonn, Bonn, Germany, October 11-13, 2006. Available on line at: http:// www.tropentag.de/2006/abstract/full/351.pdf. August 11, 2010.

Ibrahim A, D Gillon and R Joffre. 2010. Leaf litter decomposition of Mediterranean tree species in relation to temperature and initial water imbibitions under microcosm experiment. Res J Agric Biol Sci 6 (1): 32-39.

Jordan CF. 1985. Nutrient cycling in tropical forest ecosystems. Ney York: John Wiley \& Sons.

Lal R, J Kimble and R Follett. 1998. Need for research and need for action. In: R Lal, JM Kimble, RF Follett and BA Stewart (eds.), Management of carbon sequestration in soil. CRC Press, Boca Raton, pp. 447-454.

Parsakhoo A and H Jalilvand. 2009. Effects of iron wood (Parrotia persica C.A. Meyer) leaf litter on forest soil nutrient content. Am-Eur J Agric Environ Sci 5 (2): 244-249.

Prescott CE. 2005. Do rates of litter decomposition tell us anything we really need to know? For Ecol Manag 220: 66-74.

Rosleine D, DN Choesin and E Sulistyawati. 2006. The contribution of dominant tree species to nutrient cycling in mixed forest ecosystem on Mont Tangkubanperahu, West Java, Indonesia. In: Anonim (ed), International Conference on Mathematics and Natural Sciences (ICMNS).
November 29-30, 2006. Bandung, Indonesia, pp 378-380.

Ruan H, Y Li and X Zou. 2005. Soil communities and plant litter decomposition as influenced by forest debris: variation across tropical riparian and upland sites. Pedobiologia 49: 529-538.

Shrestha R and R Lal. 2008. Offsetting carbon dioxide emissions through minesoil reclamation. In: CJ Cleveland (ed), Encyclopedia of Earth. Environmental Information Coalition, National Council for Science and the Environment. Washington, D.C.

Silver WL, O Ostertag and AE Lugo. 2000. The potential for carbon sequestration through reforestation of abandoned tropical agricultural and pasture lands. Restoration Ecol 8 (4): 394-407.

Singh AN, DH Zeng, DH and FS Chen. 2006. Effects of young woody plantations of carbon and nutrient accretion rates in a redeveloping soil on coalmine spoil in dry tropical environment, India. Land Deg Develop 17: 13-21.

Sulaeman, Suparto and Eviati. 2005. Petunjuk Teknis Analisis Kimia Tanah, Tanaman, Air, dan Pupuk. Balai Penelitian Tanah, Badan Penelitian dan Pengembangan Pertanian, Departemen Pertanian. Bogor. 136p.

Tian G. 1998. Effect of soil degradation on leaf decomposition and nutrient release under humid tropical conditions. Soil Sci 163 (11): 897-906.

Tripathi G, R Kumari, and BH Sharma. 2005. Association of soil mesofauna with litter decomposition. Cientifica Jaboticabal 33(2): 148-150.

Tripathi OP, HN Pandey and RS Tripathi. 2009. Litter production, decomposition and physic-chemical properties in 3 developed agroforestry systems of Meghalaya, Northeast India. African. J Plant Sci 3(8): 160-1167.

Vivanco L and AT Austin. 2008. Tree species identity alters forest litter decomposition through long-term plant and soil interactions in Patagonia, Argentina. J Ecol 96: 727-736.

Yang YS, P Lin, JF Guo, Jian-Fen, RY Lin, GS Chen and ZM He. 2003. Litter production and leaf-litter decomposition in natural and monoculture plantation forests of Castanopsis kawakamii in Subtropical China. Available online at http:// www.fao.org/DOCREP/ARTICLE/ WFC/XII/ 0178-B4.HTM, Accessed on 17-7-2009.

Xiong Y, H Xia, Z Li, X Cai and S Fu. 2008. Impacts of litter and understory removal on soil properties in a subtropical Acacia mangium plantation in China. Plant Soil 304: 179-188. 